\title{
Advantage and Disadvantage of Foreign Migrant Fishermen in Small-Scale Fisheries toward Rural Coastal Areas
}

\author{
Cheng-Wen Lee ${ }^{1}$ and Chi-Hsi Wang ${ }^{2}$
}

\begin{abstract}
This research aims to explore the advantage and disadvantage of hiring foreign migrant laborers by small-scale fisheries (SSFs) toward rural coastal areas. The targeted groups are migrant fishermen coming from Indonesia who work onboard Taiwan's fishing boats within Nanfangao area.

First of all, we outline the importance of SSFs, particularly in developing countries. Many SSFs are characterized by self-governing mechanisms that have significant conservation value. This study is not only an exploratory research to find out and discover the range and scope of issues and concepts, but also is an explanatory research to explain how or why things are used to predict, which is carried out to investigate in a timely manner a phenomenon, that has not been studied before, or has not been well explained previously. As a result, this study indicates that the future research needs to demand priority and generate operational definitions for building a better-researched model.
\end{abstract}

JEL classification numbers: F16, F60, H13.

Keywords: Foreign Migrant Labor, Small-Scale Fisheries, Rural Coastal Areas.

\footnotetext{
1 Department of International Business, Chung Yuan Christian University, Taoyuan City, Taiwan.

${ }^{2}$ Ph.D Program in Business, College of Business, Chung Yuan Christian University, Taoyuan

City, Taiwan.
}

Article Info: Received: May 28, 2021. Revised: June 16, 2021.

Published online: June 21, 2021. 


\section{Introduction}

Small-scale fisheries (SSFs) are distinctive from large-scale industrial fisheries not only by the scale of exploitation but also by the way in which they contribute to the well-being of fishing communities (Kiyama and Yamazaki, 2018). The importance of SSFs has been increasingly recognized in terms of their role in resource management and their global contribution to food security and poverty reduction (Allison and Ellis, 2001; Weeratunge et al., 2014). About 90\% of those employed in wild-capture fisheries are involved in SSFs. Moreover, SSFs make an important contribution to local economies in rural coastal areas where alternative sources of income and employment are limited (Stobutzki, Silvestre, and Garces, 2006).

Global concern about the status of fish and other aquatic resources, therefore, poses a risk to the well-being and the social and economic development of fishing communities that directly depend on these resources (Béné et al., 2016). SSFs in developing countries are generally considered to be fishing activities that use lower technology, smaller boats and operate closer to shore; are often anchored in local communities through cultural, traditions and values that support social cohesion (Smith and Basurto, 2019). The catch is important to local consumption but may also supply national and international markets and generate income to support local and national economies. SSFs are businesses and can be categorized in business terms. SSFs often consist of household, micro and small business that are largely informal enterprises as categorized by The International Labor Organization (2002). International fishery trade can play an important role in the development strategies of many developing countries, and it is the cornerstone of many fishing communities throughout the world. For developing countries, the fisheries sector is a major source of export revenue, a key dietary input and an important provider of local livelihoods. Nearly a billion people worldwide depend on fish as their primary source of dietary protein (Schorr, 2005). Further, SSFs form a significant part of the fisheries sector though their actual contribution to total capture fishery products remains difficult to estimate. In the past several decades, bilateral fisheries access agreements between developed and developing countries have emerged as a critical part of trade relations between developed and developing countries. While these agreements have the potential to help build capacities in developing countries and maintain fishing communities in developing countries, they can also fuel overexploitation of fisheries resources in developing country national waters by distant water fleets that are provided access under the agreement while reducing the competitiveness of the local industry (ICTSD, 2006). The top capture fisheries producers were China, Peru, the United States, Indonesia, Japan, Chile, India, the Russian Federation, Thailand and Norway. International trade plays a significant role in the fisheries sector. Over the past 30 years, international trade has grown significantly and over 50 percent of the value of fisheries production and almost 40 percent of the live weight equivalent now enter international trade. The opportunity to generate profits and foreign exchange from increased trade could be one way to focus the minds of some countries on the need to ensure sustainability as a way to 
safeguard long-term economic opportunities. In some instances, trade measures have been proposed as possible avenues to address some of the drivers of fish stock depletion, including the use of import controls, traceability systems and labelling schemes which take into account developing countries' capacity constraints to implement and comply with such measures (ICTSD, 2006).

\section{Foreign Migrant Fishermen in Taiwan}

Migrant fishers hired overseas to work predominantly in international waters and the waters of other countries are covered by the Regulations on the Authorization and Management of Overseas Employment of Foreign Crew Members promulgated by Taiwan Council of Agriculture. However, the Labor Standards Act, the national labor law administered by the Ministry of Labor, only applies to migrant fishers who are hired domestically to work predominantly in national waters (Taiwan Ministry of Labor). Migrant fishermen hired overseas are not entitled to the same labor rights (e.g. freedom of association and collective bargaining), wages, insurance, and pensions as those hired domestically (United States Department of State, 2018; Yilan Migrant Fishermen Union, 2019).

Three common gaps or weaknesses in Taiwan's legal framework for DWF are minimum wage, labor recruitment, and labor inspection. Taiwan Migrant fishermen in Taiwan's DWF fleet are currently paid USD 450 per month. The national minimum wage under the Labor Standards Act is approximately USD 740 per month. Because of the two-tiered system, each migrant fisherman in Taiwan's DWF fleet is losing roughly USD 3,480 per year and the combined total loss of all Southeast Asian migrant fishers (Indonesia, Philippines, and Vietnam) is approximately USD 71,232,120 per year. In addition, Taiwan does not regulate foreign recruiters of migrant crew in their DWF fleets. This lack of oversight has resulted in debt bondage and other recruitment-related abuses (Financial Times, 2018). Moreover, Taiwan's fishery agencies have little to no capacity or expertise to conduct labor inspections on their DWF fleets. As a result, victims of forced labor are not identified as such and weak inspection regimes do not deter labor abuses in their DWF industries (Environmental Justice Foundation, 2018; Advocates for Public Interest Law, 2017).

In Taiwan, immigrant workers play an important role in fisheries but they are easily ignored by society. Taiwan's young populations from rural areas have migrated to metropolitan areas and favored tertiary job sectors that have increased economic development. The provision of labor for primary sectors, including fisheries, has been greatly reduced nationwide. Since 1992, the government of Taiwan has allowed immigrant workers into the country with three-year short-term working visas. In 2018, over 670,000 official immigrant workers worked in Taiwan, including 12,305 working for commercial fisheries (WDA2018). Individuals working in fisheries make up a small proportion of all immigrant workers and their issues may be easily ignored and can be difficult to investigate due to relatively closed and offshore labor environments. The poor conditions of immigrant workers, 
including their labor rights and environments, have been a global issue, and Taiwan is no exception (Benach et al., 2010; Brown, Jones, and Becker, 2018). The roles these individuals have played in commercial fisheries have been invaluable for Taiwan, however the related problems and characteristics of immigrant workers in fisheries remain unclear.

In recent years, owing to factors such as sluggishness in the Taiwan's economy and extremely competitive international markets and the hike in the minimum wage in Taiwan, some business enterprises and scholars have advocated decoupling of foreign workers' wages from the minimum wage. They argue that it would lower labor costs and encourage companies that have relocated their units elsewhere to return to Taiwan. When examining the economic effects of the minimum wage through empirical studies, most economists choose to focus mainly on the impact of the minimum wage on employment (Hwang, Wang, and Chung, 2011). Most time series studies relating to the economic effects of the minimum wage have been conducted in the U.S. The majority of empirical results lead to the conclusion that an increase in the minimum wage has a negative impact on employment, i.e. it raises unemployment rate (Neumark and Wascher, 2008). The research was found that of the 86 international studies surveyed, the vast majority indicated that minimum wage increases had a negative effect on employment. They compiled results from a substantial number of empirical studies conducted in the 1990s, and these data also support the notion that upward adjustment of the minimum age lowers the employment rate (Neumark and Wascher, 2008). Meta-analysis of such studies showed that a large majority indicate negative effects of the minimum wage; those showing positive effects are few, questionable, and disproportionately discussed (Neumark and Wascher, 2008).

However, another empirical study was examined to see how minimum wage laws affect employment and earnings of low-skilled immigrants and natives in the U.S., and found that minimum wages did not have adverse employment effects on adult immigrants or natives who did not complete high school. Potential explanations for these results include imperfectly competitive labor markets, decrease in hours worked per worker, instead of in the number of workers, and improvements in the quality and productivity of workers that offset the effects of higher wage mandates (Orrenius and Zavodny, 2008). Decoupling foreign workers' wages from the minimum wage may lead to wage discrimination and employers may find it more difficult to hire quality foreign worker to replenish their human resources. Not only that, the odds of laborers skipping work or labor disputes erupting would probably be higher, thus resulting in a negative impact on the morale of foreign workers. Furthermore, decoupling foreign workers' wages from minimum wage might also lead to negative impact on local workers in Taiwan because foreign workers would become cheap replacements for local workers, encouraging employers to exploit their workers even more; this would suppress the wage level for domestic unskilled workers (Hwang, Wang, and Chung, 2011).

Some scholars hold opposing viewpoints on this issue. Based on human capital theory and dual-labor market theory in fundamental economic theory, they have 
argued that the market for foreign workers is in fact separated from the domestic labor market. For example, Becker (1960) proposed that the level of laborer's education can be used as a criterion to differentiate workers' wages, whereas Spence and Ogilvie (1973) maintained that qualifications and academic degrees serve as an important signal and criterion that employers can use in their search for ideal workers. In other words, these scholars suggest that as long as the level of education of domestic workers is higher than that of foreign workers, their wage levels and employment opportunities are unlikely to be affected by the presence of foreign workers and as such, foreign workers and domestic labors are naturally categorized by their level of education. Given the principles of limited supplementation by foreign workers, with restrictions on their duration of stay, we can deduce that the government wishes to minimize the impact on local laborers' rights and benefits. In other words, the foreign worker policy adopted by the government is inclined more towards the "segmentation hypothesis" rather than the "replacement hypothesis" (Briggs, 1975). If the segmentation hypothesis is indeed true, decoupling foreign workers' wages from the minimum wage should not affect domestic workers' wage levels. Importing foreign fishermen is to supplement for the labor shortages in fishery business.

From the perspective of international trade, since Taiwan is a member of the World Trade Organization (WTO), all trade and commerce (including the labor market) regulations have to be compliant with requirements for the national treatment for foreign workers. In terms of working conditions, there should not be any discriminatory treatment for foreign workers. Decoupling of foreign workers' wages from the minimum wage would not only reflect the government's lack of regard for basic human rights but also a lack of respect for the spirit of national treatment. It is entirely possible that the decision would cause labor exporting nations and relevant members of international trade organizations to protest or impose trade boycott or sanctions. It should be apparent that the argument for decoupling foreign workers' wages from the minimum wage to cut labor costs and boost our products' competitiveness in the world would only backfire (Hwang, Wang, and Chung, 2011).

\section{Foreign Migrants Reshaping SSFs}

At all Taiwan's fishing ports including Nanfangao, the fishing boats won't be operated if without those foreign migrants (both the regular foreign workers and the overseas hired migrant fishermen). The fishery business has being seen a significant increase in reliance on foreign migrant workers through the lower-skilled stream (Knott and Neis, 2017; Baker, 2012). For reasons of the local fishermen shortage, fishery company representatives and other local observers point to how many younger people are no longer interested in this type of job (Thomas and Belkhodja, 2014), in part due to the seasonal and unpredictable nature of fisheries related work (e.g., weather, catch), and long working hours. Worth noting, the average age of fishery worker is 50 years old or above, with many local workers nearing retirement 
(Thomas and Belkhodja, 2014). Those foreign fishermen provide necessary man power to the Taiwan's fishery business, and they also bring the new culture of reshaping the Taiwan's fishing towns.

Both scholars and many public actors have argued that employers have used these foreign migrant fishermen to lower wages and increase flexibility, while displacing better paid domestic workers (Preibisch, 2010). The rise of migrant workforce is linked to a general reshaping of regional fisheries from family-based fisheries towards corporate, financialized seafood processing (Knott and Neis, 2017), as seafood producers increasingly compete with producers in low-wage environments such as those based in Southeast Asia (Couper, Smith, and Ciceri, 2015). The fishery sector has not been the subject of significant inquiry (Hein, 2006; Baker, 2012; Thomas and Belkhodja, 2014; Knott, 2016) even as fishery labor abuse scandals have erupted globally (Couper, Smith, and Ciceri, 2015; Marschke and Vandergeest, 2016). Most often, however, migrant workers are recruited through private actors or recruiting agencies, who offer a range of services including screening, hiring, arranging transportation, translation, and completing work permit applications (Hennebry and Preibisch, 2012). Although charging recruitment and immigration fees to workers is illegal in many countries, the practice is widely reported by nongovernmental organizations and academic researchers (Hennebry and Preibisch, 2012). Foreign migrant fishermen often experience significant antifreedom to working conditions (Marschke, Kehoe, and Vandergeest 2018). Labor abuse scandals have also surfaced beyond the global South, as recently seen in Ireland, Hawaii, and Taiwan (Kittinger et al., 2018). While foreign migrant experiences vary, there are reports of fraud, misrepresentation of jobs, withholding of information, and extensive pay deductions (Muir et al., 2016).

At the same time, Knott (2016) and Knott and Neis (2017) have shown how drawing on migrant labor-particularly in a context of privatization, globalization, and financialization-can lower wages and worsen working conditions, rendering such jobs unacceptable to the local population. Seafood is a perishable good that requires timely handling to ensure freshness and quality, and often involves physically challenging tasks including offloading boats and manual work in processing facilities (Castellanos Contreras, and Rebert, 2016). Flexibility in the availability of workers willing and able to complete these tasks is an important labor force characteristic for the Fishery sector (Marschke, Kehoe, and Vandergeest, 2018). 


\section{Two-Tiered System of Distance Water Fishery}

Even though seafood processing generally pays low wages, seafood can be profitable for some (Fisheries and Oceans Canada, 2017). The ASEAN Community, especially the countries of origin of workers aboard the Taiwanese and South Korean Distance Water Fishing (DWF) fleets, has long allowed unequal treatment and associated human rights violations despite numerous commitments to promoting and protecting the human rights of its people, as well as preserving the marine environment. The "two-tiered system" used by Taiwan and South Korean to exclude foreign migrant fishermen in their DWF fleets from the scope of protection of national labor or employment laws is a de facto labor subsidy. The two tiered system was developed precisely to cut costs as the Taiwanese and South Korean DWF fleets would find it more challenging to maintain an edge on their competitors - and satisfy the demands of buyers - if their migrant crew were paid the national minimum wage and afforded the same rights and benefits as Taiwanese and South Korean crew. The higher rate of labor abuse in these fleets due to less regulation and weaker enforcement also reduces costs for vessel owners and the industry as a whole.

Realizing this vision requires caring for the tens of thousands of ASEAN migrant workers who currently face discrimination and exploitation in the Taiwanese and South Korean DWF fleets. The two-tiered system in these countries not only rob migrant fishermen's earnings that could help support their families at home, but also income that could help strengthen their countries' economic development. The system also increases migrant fishers' risk of forced labor and human trafficking and infringes on their fundamental right to freedom from discrimination. Distantwater fishing is fishing in areas far removed from a country's domestic waters (Tickler at al., 2018). The increased fishing capacity of engine-powered trawlers led to greatly improved catches, but their introduction was soon followed by signs of depletion in coastal fish stocks and conflict with smaller inshore fishers (Knauss, 2005). Vessels capable of moving further offshore did so, targeting less heavily exploited fishing grounds and beginning a process of progressive spatial expansion. While most countries fished largely in local waters, Taiwan, South Korea, Spain, and China rapidly increased their mean distance to fishing grounds by 2000 to 4000 $\mathrm{km}$ between 1950 and 2014. Others, including Japan and the former USSR, expanded in the postwar decades but then retrenched from themid-1970s, as access to other countries' waters became increasingly restricted with the advent of exclusive economic zones formalized in the 1982 United Nations Convention on the Law of the Sea. Since 1950, heavily subsidized fleets have increased the total fished area from $60 \%$ to more than $90 \%$ of the world's oceans, doubling the average distance traveled from home ports but catching only one-third of the historical amount per kilometer traveled. Catch per unit area has declined by $22 \%$ since the mid-1990s, as fleets approach the limits of geographical expansion. As Figure 1 shows, allowing these trends to continue threatens the bio-economic sustainability of fisheries globally (Tickler et al., 2018). 
To keep vessels fishing, fuel costs may be partly offset by generous government subsidies (Sumaila et al., 2016; Mallory 2016), and there is a good correlation between the distance a country fishes from home and the level of subsidies paid for fuel, vessel, and fleet support. In the case of Taiwan, these payments amount to more than $80 \%$ of the landed value of the industrial fishing catch. The relationship between subsidies and fishing distance suggests that expansion has been driven, in large part, by national policies that actively promote distant water fishing through the provision of fuel and vessel subsidies. A recent analysis of the economics of high seas fishing found that profits from these activities for the major distant-water fishing countries would be greatly reduced, or even disappear completely, if fleets were not subsidized (Sala et al., 2018). While governments continue to subsidize fleet expansion, the labor costs of these operations can typically only be reduced by cutting back on crew numbers, pay, or working conditions, which may be contributing to the growing tally of human rights and labor abuses that have been recorded on fishing vessels (Marschke and Vandergeest, 2016; Kroodsma et al., 2018). Illegal fishing and the use of flags of convenience can also serve to reduce the cost component for vessels suffering diminishing returns (Österblom et al., 2011).
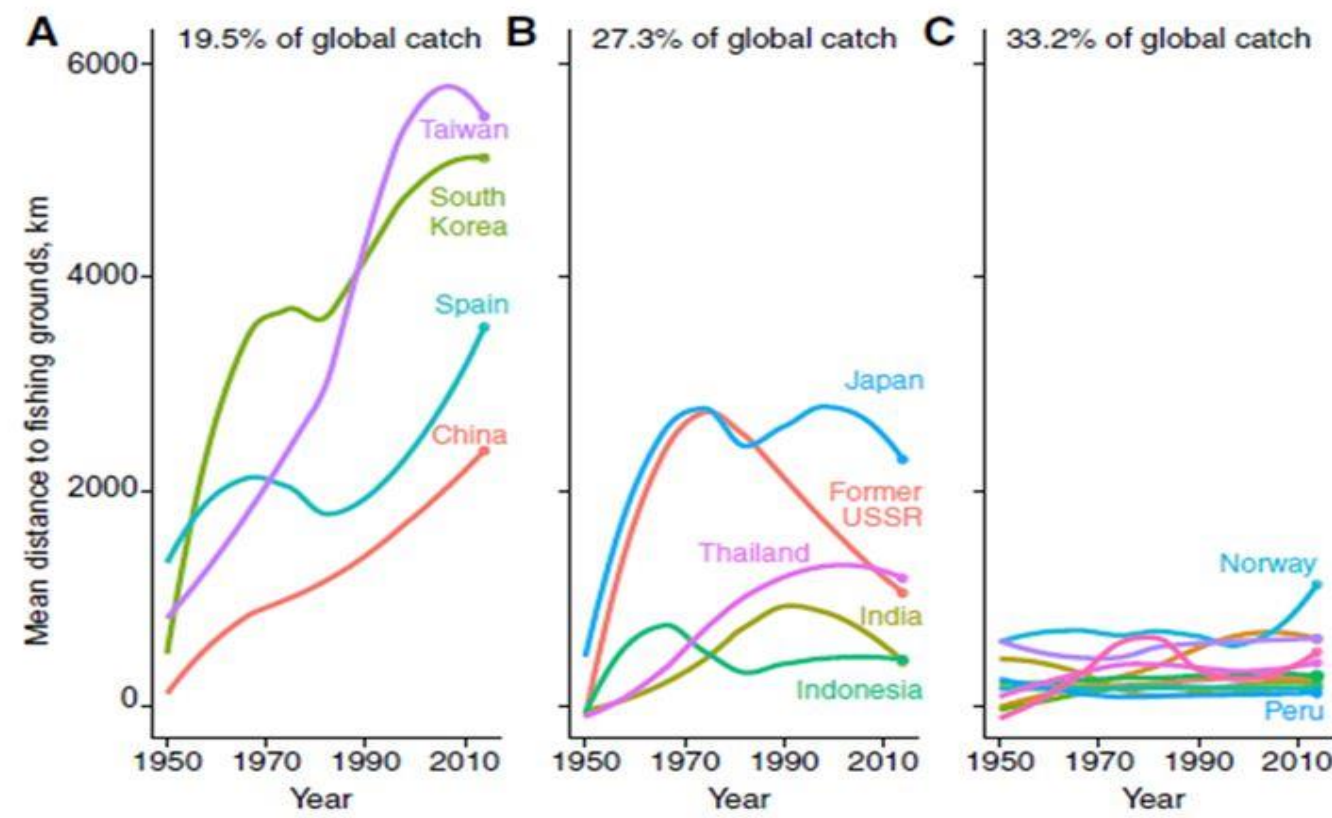

Source: Tickler et al. (2018)

Figure 1: Trends in the Distance Traveled to Fish from 1950-2014 


\section{Indonesian Action to Protect Migrants}

Indonesia's government is taking steps to protect workers in the fishing industry, including 22,000 Indonesians aboard Taiwanese boats, cited by a maritime affairs official, after Greenpeace reported that nearly three dozen had been subjected to "forced labor." The government recognizes that there is a lack of clear regulations on the recruitment and placement of workers on domestic and foreign fishing boats, quoted by a senior official at the Coordinating Ministry for Maritime Affairs. The government is aware that there are many cases of human trafficking, forced labor and modern slavery at sea in the fishing sector, both on national and foreign boats; the Indonesian National Team for the Protection of Seafarers and Fishing Ship Crew Members, which was formed recently, was working to improve training and protection. Existing laws on sea navigation and fishermen protection do not specifically address the issue of local and migrant workers working as crew members on fishing boats. This will be a fundamental and comprehensive overhaul in the fisheries sector, which had been overlooked in the past.

The Ministry of Manpower (MoM) is the institution responsible for labor affairs in Indonesia under the labor law. It is mandated to manage overseas labor migration. Indonesia has a long history of labor migration and is one of the largest providers of migrant workers in Southeast Asia. Labor migration can be beneficial to workers, their families and the Indonesian economy. However, many migrant workers are exposed to decent work deficits. Migrant fishers may face additional challenges because of their unique on/offshore status, falling through protection gaps in the laws, regulations and measures that countries have established to protect land-based workers. Fishers are often employed by third parties, such as Private Employment Agencies (PrEAs), rather than directly by the fishing vessel owner. Lack of transparency regarding the recruitment process increases the risk of harm to the migrant fisher abroad. Illegal and fraudulent recruitment and placement practices may also lead to human trafficking and forced labor (ILO, 2020).

While most migrant workers originating from Indonesia are in land-based occupations, such as domestic work and construction, substantial numbers of Indonesian migrant fishers are recruited, through both formal and informal channels, to work on vessels flagged to other countries and in foreign waters. Labor migration can be beneficial to the workers, their families, and the Indonesian economy through acquired skills and remittances, which totaled over 8 billion US dollars (USD) in 2016, around 1 per cent of the country's gross domestic product (GDP) (WorldBank, 2017). (See Figure 2).

Migrant fishers may face challenges in accessing social protection including health care and social security due to their unique status as off-shore workers, falling through protection gaps in the laws, regulations and measures that countries have established to protect land-based workers (ILO, 2017). In addition, restrictions on fishers' freedom of association and collective bargaining; forced labor; unpaid wages; unsafe work conditions; inadequate rest; inhumane housing conditions; fundamental changes in the nature or conditions of work; confiscation of workers' 
identity documents by employers; and even physical abuse have been reported (IOM, 2015). Upon return to Indonesia they may face challenges accessing insurance payments and finding job opportunities.

While Indonesia does not have diplomatic relations with Taiwan, there are substantial numbers of Indonesian fishers on board Taiwanese-flag fishing vessels, sent by Kantor Dagang dan Ekonomi Indonesia di Taipei, an economic and trade agency. Previous reports by have uncovered several accounts (some anecdotal but most supported by empirical evidence) of Indonesian migrant workers who were abused during their employment at sea. These accounts suggest that the abuse commonly faced by workers include verbal assault, physical violence, unlawful confinement and the restriction of access to basic human necessities (EJF, 2018). Indonesia's representation in Taipei includes seconded staff from the MoM and the BNP2TKI (National Agency for the Placement and Protection of Indonesian Migrant Workers), including a labor section head, senior assistant and analyst to respond to demands of land and sea-based migrant workers from Indonesia. Over 4,300 migrant worker complaints were processed between 2014 and 2017. Common issues were the lack of work agreements and non-payment of wages. There are two types of placement for Indonesian migrant fishers: (1) Official government-togovernment placement through the BNP2TKI; and (2) Letter-guaranteed privateto-private entity placement (Greenpeace European Unit, 2019). Indonesian migrant fishers working on domestic Taiwanese fleets are registered through the official placement and protected under Taiwanese law. However, most migrant fishers operating outside Taiwanese waters fall under letter-guaranteed placement, which makes them more vulnerable to exploitation. Most of the Indonesian migrant fishers assisted by the IOM in Indonesia fall into this category (IOM, 2016). 


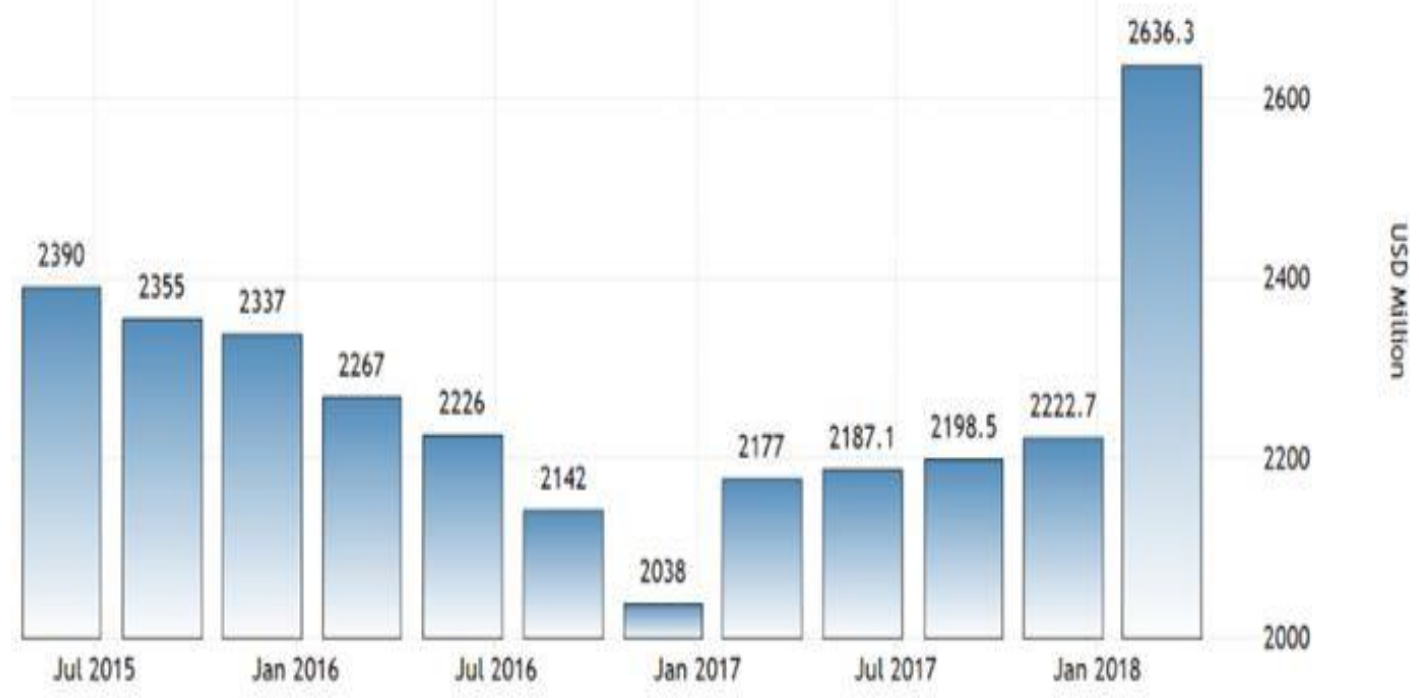

Source: Trading Economics.Com/Bank Indonesia

Figure 2: Indonesia Remittances

\section{Economic/Social Benefit of Non-Local Labor}

There was evidence of some studies that non-local labor plays an important role supporting certain sectors, sub-sectors and enterprises - including fisheries subsectors, and generally stakeholders proposed that economic contributions were positive. In a number of case studies, it was even reported that non-locals were creating new enterprises, and therefore significantly contributing to the local economy. In terms of social contributions, there was a great deal of evidence to suggest that in the most part non-local workers in the fisheries sector have a positive contribution and aim to assimilate to the extent possible within their communities. Amongst fishermen non-local fishermen in the catching sub-sector there was clear evidence of significant remittances being paid back to countries of origin, although the extent and value of these remittances is unclear. This is an important point, as many regions are considered to have ageing populations, and therefore the influx of young non-locals is important to support the populations socially and economically. This is noteworthy, as it indicates the positive role non-locals play in the social structure of the city. Although there were examples of communities of non-local labor forces that were somewhat isolated from the rest of the community, but these tended to be the exception rather than the rule. Although some case studies reported that many non-local communities were not well integrated within local community. Cultural differences do not seem to be a restraining factor to their social participation. It is the nature of their work that functions as an inhibitor for social 
integration together with the character of many locals, who although not showing disregard towards the fishermen, are rigid and not open to creating real ties with them. The most socially excluded groups of non-local laborers were generally reported to be those employed within the distant-water fleets segment, contributing little socially, as they tend to remain on board the vessels, and then return to their country of origin when their contracts are up. However, overall many stakeholders revealed that non-local laborers supported a struggling industry especially in the catching sub-sector and to a lesser extent contributed to the aquaculture sub-sector. The only negative comments were regarding the impact of wage suppression for agricultural workers (MRAG, European Commission, 2016).

Immigration policy varies considerably from country to country. Immigration is a contentious issue in the industrialized nations of the world. Many of the key issues in the debate on immigration policy are economic. Labor economists interested in migration have focused empirically upon labor market outcomes such as wages and employment. They have typically assumed an economy with an aggregate production technology displaying constant returns to scale. Macroeconomists and international economists have paid some attention to the question of the influence of migration on (per capita) growth, which may be particularly interesting in the context of increasing returns to scale. Of course, growth would then feed back into the variables traditionally in the domain of labor economists. While recent theoretical work has made strides toward explaining the possible links between immigration and growth, only a few empirical studies have been conducted, and no clear picture has emerged from these (Friedberg and Hunt, 1995). A simple theoretical analysis can be based on a modified Solow's (1956) growth model. Production is a function of labor and human capital, which are internationally mobile, and physical capital, which is not. Assume there is no trade between countries. A country receives immigrants if it has a higher ratio of physical capital to labor, which implies a higher wage rate. Immigrants are assumed to bring no physical capital with them, but they do bring human capital and will bring more human capital if the ratio of physical capital to human capital is high. In such a model, the key to the impact of immigration is whether immigrants bring enough human capital to offset their dilution of physical capital in the receiving economy. If immigrants have little human capital, their impact is akin to that of faster population growth in slowing per capita growth. If immigrant human capital levels are higher than natives' by a sufficient amount, growth will be speeded up. The theoretical models generally predict that a migrant will move either to a country with a higher wage or a country where the expected stream of wages is higher. But if higher immigration can help create the higher wages that make that immigration attractive in the first place, then there is simultaneity between growth and migration that will be difficult to disentangle empirically. Despite the popular belief that immigrants have a large adverse impact on the wages and employment opportunities of the native-born population, the literature on this question does not provide much support for this conclusion. Economic theory is equivocal, and empirical estimates in a variety of settings and using a variety of approaches have shown that the effect 
of immigration on the labor market outcomes of natives is small. There is no evidence of economically significant reductions in native employment (Friedberg and Hunt, 1995). A paper that tackles this issue is that by Mendoza-Portillo, Ramírez-Rodríguez, and Vargas-López (2020). They include migration in an equation regressing growth in per capita income on the level of per capita income (and other variables) for Japanese and American regions in different time periods. In this context, the coefficient on the level of income indicates the rate of convergence between regions (which one could view as recovery from shocks or as short-term growth). The impact of migration on growth may be judged in two ways: by the way in which including a migration variable affects the estimated convergence coefficient and also by the actual coefficient on migration, which can be interpreted as the effect of migration on long-term growth. For both Japan and the United States, adding migration to the convergence regression raises the convergence coefficient slightly and yields a positive coefficient on migration. For the United States, this coefficient suggests that a 1 percentage point higher net migration rate is associated with a 0.1 percent higher growth rate.

\section{Disadvantage of Forced Labor in SSFs}

Environmental destruction and forced labor are negative externalities in many fisheries worldwide, with abuses largely ignored in the pursuit of catching more fish from an emptier sea (Duong, 2018). Seafood has long been a significant part of the world diet (The Food Timeline, 2018). When we sit down to a fancy seafood dinner and order sizzling Thai shrimp or grilled Hawaiian swordfish, we don't realize our meal comes with a side of slavery: it's quite likely that foreign fishermen working in slave-like conditions caught the cheap seafood on our plates (Mendoza et al., 2016). Today, the skyrocketing demand for and dwindling supply of fish create a context in which consumers are desperate for more fish faster. Fishermen would oblige, but there's just one problem: there aren't enough fish in the sea. The increasing demand for fish has resulted in expanded fishing practices globally (FAO, 2008). This expansion, coupled with technological advances, should be producing record catches. This is not the reality, and, "despite becoming more efficient and being heavily subsidized, many fishing fleets are reporting lower and lower yields." (Johnson et al., 2018) The reason is simple: overfishing is happening all over the world and the ocean is running out of fish.

Fisheries around the world are being challenged to synthesize these opposing market forces of increasing demand and dwindling, overfished supplies. Unfortunately, some fleets accomplish this by cutting costs through environmental and labor exploitation. As fish stocks continue to decline, fishing boats need to go further out to sea for longer periods of time to keep finding fish. Longer cycles at sea cost owners more in fixed costs like fuel and maintenance (Marschke and Vandergeest, 2016). Basic economics teaches us that these two supply chain influences-higher costs and scarce natural resources-should lead to an increase in the price of seafood and/or less suppliers willing to supply seafood at the same 
quantity and price. The following sentences will explore how artificial price ceilings are instead keeping prices low and creating negative externalities in the seafood market. There are some instances where these supply-and-demand basics appear at first to have proven true. Tuna, for instance, is prized around the world. As stocks of tuna dwindle, demand continues to skyrocket (Duong, 2018). The most expensive fish ever sold was a large bluefin tuna, which sold in Japan in 2013 for almost USD 1.8 million. However, even this record-breaking fish did not follow true supplydemand pricing and valuations. The restaurateur who purchased the tuna paid about USD 176 per sushi piece but sold the fish "at his restaurant chain's regular prices, which are much lower. One agency reported that the prized sushi could sell for only "up to USD 24" a piece. Suppliers of prized fish often do not pass the true supply cost of the fish along to their patrons, who would likely refuse to pay those high prices for seafood. These customers, then, do not get an accurate sense of the true cost of the fish, one that takes into account all of the costs associated with labor, environmental stewardship, and resource availability. Seafood subsidies cause the same imbalance, contributing to overcapacity and overfishing, as well as illegal, unreported, and unregulated fishing (Fraser, 2017). False price ceilings that create unrealistic and unsustainable prices for seafood ignore these negative externalities. Consumers operate under a false sense of abundance and continue demanding more cheap fish. Restauranteurs are then pressured to keep selling fish for too cheap, and seafood suppliers have to find other ways to cut their costs, like through labor and environmental exploitation. The true cost of fish is much higher than consumers will pay, and fish stocks and fishermen are taking the hit (Duong, 2018).

Some vessel owners also employ another illegal, cost-cutting endeavor that is much more insidious: labor exploitation. In fact, as the appetite for cheap fish worldwide grows, so does the demand for men who are paid little or nothing to catch it (McDowell, Mason, and Mendoza, 2015). Human trafficking is another example of abuse in the seafood industry. According to the International Labor Organization (ILO), human trafficking includes three core elements:

1. Action or activities such as recruitment, transfer, harboring, or receipt of persons.

2. Means of trafficking such as deception, force, coercion, or abuse of power or position of vulnerability.

3. Purpose for exploitation.

The fishermen are often transported illegally across national borders, often using falsified documents, threats of violence, actual violence, and exploitation of vulnerabilities. They are sold to fishing ships and seafood processing factories for the purpose of being exploited for their labor. Some fishermen become victims of trafficking by way of labor brokers. These brokers promise easy, lucrative employment to lure vulnerable, migrant men to work. Thus, the fishermen falling prey to these schemes can be considered victims of human trafficking under the accepted international ILO framework (Duong, 2018).

Forced labor is a kind of seafood slavery abuse. As the AP reports note, the 
conditions in which the victims of slavery and human trafficking are forced to work are often squalid. The blurry line between migrant workers who willingly work for low wages in poor conditions and those who are victims of forced labor hinges on the ILO definition of forced labor. This definition-"all work or service which is exacted from any person under the menace of any penalty for which the said person has not offered himself voluntarily (Forced or Compulsory Labor Convention, 1930)-analyzes how workers end up in poor conditions. The "menace of penalty" implies subjection to coercion, and "involuntariness" refers to work people would not otherwise accept. Fishermen report threats and actual abuses, withholding of food, medical and mental health treatments, and protection, and use of "enforcers" to extract faster work from them (Duong, 2018). Once aboard the boats, the foreign fishers find themselves trapped and isolated. They are kept for years at a time aboard long-haul boats, vessels that stay at sea. These boats rarely, if ever, go to shore, limiting the captive men's chances of escape. Instead, supply boats come to the long-haul boats to provide supplies, fuel, ice, and new workers. Men are often traded from boat to boat on the open sea. Even worse, murders on the high seas are not uncommon (Fischman, 2017).

\section{Further Implications}

Corporate and consumer awareness and responsibility campaigns can also be leveraged to combat seafood slavery. While these avenues are not legally binding, they do provide important and potentially powerful opportunities for change. Many consumers and smaller distributors recognize that large corporations are the ones who act like the pope as far as sustainability and human rights, but then they go out and buy from the main culprits. There are very few corporations looking deep into their supply chains to ensure that they are not guilty of these very practices they openly disavow. In contrast, most corporations are reluctant to exercise their power as customers of tainted supply chains. They strongly condemn labor abuses and vow to take steps to prevent it, but claim that if they stopped buying tainted seafood, then they would no longer be in the conversation anymore about labor, then they would not have the ability to fix it. They would not have the ability to push for change. Examples of corporate social responsibility and leadership are rare and need to become more common if we are to begin eradicating supply chains of this modernday slavery (Rodrigues, Harris, and Mason, 2015). This study is not only an exploratory research to find out and discover the range and scope of issues and concepts, but also is an explanatory research to explain how or why things are used to predict, which is carried out to investigate in a timely manner a phenomenon, that has not been studied before, or has not been well explained previously. As a result, this study indicates that the future research needs to demand priority and generate operational definitions for building a better-researched model. 


\section{References}

[1] Allison, E. H. and Ellis, F. (2001). The livelihoods approach and management of small-scale fisheries. Marine policy, 25(5), pp. 377-388.

[2] Baker, J. (2012). Changing Hands: Temporary Foreign Workers in Prince Edward Island. Charlottetown, PEI: Cooper Institute.

[3] Becker, H. S. (1960). Notes on the concept of commitment. American Journal of Sociology, 66(1), pp. 32-40.

[4] Benach, J., Muntaner, C., Chung, H., and Benavides, F. G. (2010). Immigration, employment relations, and health: Developing a research agenda. American Journal of Industrial Medicine, 53(4), pp. 338-343.

[5] Béné, C., Arthur, R., Norbury, H., Allison, E. H., Beveridge, M., Bush, S. and Williams, M. (2016). Contribution of fisheries and aquaculture to food security and poverty reduction: assessing the current evidence. World Development, 79, pp. 177-196.

[6] Briggs Jr. V. M. (1975). Mexican workers in the United States labor market: A contemporary dilemma. International Labor Review, 112, p. 351.

[7] Brown, H. E., Jones, J. and Backer, A. (2018). The racialization of Latino immigrants in new destinations: Criminality, ascription, and counter mobilization. RSF: The Russell Sage Foundation Journal of the Social Sciences, 4(5), pp. 118-140.

[8] Castellanos Contreras, D. and Rebert, T. (2016). Raising the floor for supply chain workers: Perspective from U.S. seafood supply chains. Workers Voices from the Global Supply Chain Report. New Orleans, LA: National Guestworker Alliance.

[9] Couper, A., Smith, H. D. and Ciceri, B. (2015). Fishers and Plunderers: Theft, Slavery and Violence at Sea. London, UK: Pluto Press.

[10] Duong, T. T. (2018). The true cost of cheap seafood: An analysis of environmental and human exploitation in the seafood industry. Hastings Environmental Law Journal, 24, p. 279.

[11] Fischman, K. (2017). Adrift in the sea: the impact of the business supply chain transparency on Trafficking and Slavery Act of 2015 on forced labor in the Thai fishing industry. Indiana Journal of Global Legal Studies, 24(1), pp. 227252.

[12] Fraser, N. (2017). A triple movement? Parsing the politics of crisis after Polanyi. In Beyond Neoliberalism (pp. 29-42). Palgrave Macmillan, Cham.

[13] Friedberg, R. M. and Hunt, J. (1995). The impact of immigrants on host country wages, employment and growth.

Journal of Economic perspectives, 9(2), pp. 23-44.

[14] Hein, T. (2006). Labor pains. Food in Canada, 66(9), pp. 26-29.

[15] Hennebry, J. L. and Preibisch, K. (2012). A model for managed migration? Re-examining best practices in Canada's seasonal agricultural worker program. International Migration, 50, pp. e19-e40. 
[16] Hwang, J. T., Wang, C. H. and Chung, C. P. (2011). Is it possible to decouple foreign workers' wages from the minimum wage in Taiwan? The Economic and Labor Relations Review, 22(2), pp. 107-130.

[17] Johnson, G. C., Lyman, J. M., Boyer, T., Cheng, L., Domingues, C. M., Gilson, J., Ishii, M., Killick, R., Monselesan, D., Purkey, S. G. and Wijffels, S. E. (2018). Ocean Heat Content in State of the Climate in 2017, Bulletin of the American Meteorological Societ.

[18] Knauss, J. M. (2005). The growth of British fisheries during the industrial revolution. Ocean Development \& International Law, 36(1), pp. 1-11.

[19] Kittinger, J. N., Teh, L. C., Allison, E. H., Bennett, N. J., Crowder, L. B., Finkbeiner, E. M. and Wilhelm, T. A. (2017). Committing to socially responsible seafood. Science, 356(6341), pp. 912-913.

[20] Kiyama, S. and Yamazaki, S. (2018). The impact of stock collapse on smallscale fishers' behavior: evidence from Japan. Canadian Journal of Fisheries and Aquatic Sciences, 75(12), pp. 2241-2254.

[21] Knott, C. (2016). Contentious mobilities and cheaper labor: Temporary foreign workers in a New Brunswick seafood processing community. Canadian Journal of Sociology, 41(3), pp. 375-397.

[22] Knott, C. and Neis, B. (2017). Privatization, financialization and ocean grabbing in New Brunswick herring fisheries and salmon aquaculture. Marine Policy, 80, pp. 10-18.

[23] Kroodsma, D. A., Mayorga, J., Hochberg, T., Miller, N. A., Boerder, K., Ferretti, F. and Worm, B. (2018). Tracking the global footprint of fisheries. Science, 359(6378), pp. 904-908.

[24] Marschke, M. and Vandergeest, P. (2016). Slavery scandals: Unpacking labor challenges and policy responses within the off-shore fisheries sector. Marine policy, 68, pp. 39-46.

[25] McDowell, R., Mason, M. and Mendoza, M. (2015). AP Investigation: Are Slaves Catching the Fish You Buy. Associated Press.

[26] Mendoza-Portillo, F. J., Ramírez-Rodríguez, M. and Vargas-López, V. (2020). Interactions of small-scale fisheries in Mexico's northwest Pacific. Latin American Journal of Aquatic Research, 48(1), pp. 94-105.

[27] Muir, P., Li, S., Lou, S., Wang, D., Spakowicz, D. J., Salichos, L. and Gerstein, M. (2016). The real cost of sequencing: scaling computation to keep pace with data generation. Genome biology, 17(1), pp. 1-9.

[28] Neumark, D., Wascher, W. L. and Wascher, W. L. (2008). Minimum Wages. MIT Press.

[29] Orrenius, P. M. and Zavodny, M. (2008). The effect of minimum wages on immigrants' employment and earnings. ILR Review, 61(4), pp. 544-563.

[30] Österblom, H. (2014). Catching up on fisheries crime. Conservation Biology, 28(3), p. 877.

[31] Preibisch, K. (2010). Pick-your-own labor: Migrant workers and flexibility in Canadian agriculture 1. International Migration Review, 44(2), pp. 404-441. 
[32] Rodrigues, V. S., Harris, I. and Mason, R. (2015). Horizontal logistics collaboration for enhanced supply chain performance: an international retail perspective. Supply Chain Management: An International Journal.

[33] Schorr, D. K. (2005). Artisanal fishing: Promoting poverty reduction and community development through new WTO rules on fisheries subsidies: An Issue and Options, Working Paper.

[34] Smith, H. and Basurto, X. (2019). Defining small-scale fisheries and examining the role of science in shaping perceptions of who and what counts: A systematic review. Frontiers in Marine Science, 6, p. 236.

[35] Spence, I. and Ogilvie, J. C. (1973). A table of expected stress values for random rankings in nonmetric multidimensional scaling. Multivariate Behavioral Research, 8(4), pp. 511-517.

[36] Stobutzki, I. C., Silvestre, G. T. and Garces, L. R. (2006). Key issues in coastal fisheries in South and Southeast Asia, outcomes of a regional initiative. Fisheries Research, 78(2-3), pp. 109-118.

[37] Thomas, E. and Belkhodja, C. (2014). Temporary foreign workers in New Brunswick's rural communities. Journal of New Brunswick Studies/Revue d'études sur le Nouveau-Brunswick, 5, pp. 66-80.

[38] Tickler, D., Meeuwig, J. J., Bryant, K., David, F., Forrest, J. A., Gordon, E. and Zeller, D. (2018). Modern slavery and the race to fish. Nature Communications, 9(1), pp. 1-9.

[39] Weeratunge, N., Béné, C., Siriwardane, R., Charles, A., Johnson, D., Allison, E. H. and Badjeck, M. C. (2014). Small-scale fisheries through the wellbeing lens. Fish and Fisheries, 15(2), pp. 255-279. 